\title{
THE EFFECT OF ORAL HYGIENE IN PROGNOSIS OF DENTAL PROSTHESIS OF PATIENTS IN PROSTHODONTICS CLINIC
}

\author{
Nadra Ahmed Ishaq* and Mohammed HassanA lsakkaf **
}

\begin{abstract}
Interventions for better oral hygiene would be more successful if the patient with dental prosthesis knows more about his oral hygiene and how to maintain it.

To assess the association between oral hygiene and its effect in the prognosis of patient with dental prosthesis or any dental restoration.

The sample was composed by 240 cases divided in four provinces (Hadramoot, Aden, Laheeg and Taiz), 60 cases for each province were clinically examined..
\end{abstract}

KEY WORDS: Oral hygiene, diabetes, dental prosthesis.

\section{INTRODUCTION}

The quality of life of a human being is determined among other things by health. Oral health is part of general health. If a person has a poor oral health this may affect his general health ${ }^{(1)}$

Behavioral interventions can be effectively used to prevent disease, improve management of existing disease, increase quality of life, and reduce healthcare costs ${ }^{(2)}$

For example the oral hygiene of a patient with dental implant prosthetics must always be extremely efficient ${ }^{(3)} \mathrm{Also}$ the presence of removable prostheses can be a factor associated with diseases and discomfort if not maintained adequately, both by dental professionals and wearers themselves ${ }^{(4)}$. Denture maintenance and hygiene usually show certain degrees of precariousness, however. One of the most frequent problems found is poor denture hygiene ${ }^{(5,6)}$, often caused by lack of instruction or age-related motor coordination problems ${ }^{(7)}$. The acquisition of better oral hygiene habits by complete denture wearers improves oral health and also increases dentures' longevity. Nevertheless, changing edentulous patients' oral hygiene habits is usually a difficult task ${ }^{(8,9)}$ Adequate cleansing habits render biofilm formation difficult, in analogy to what happens on the natural dentition ${ }^{(10)}$. 
Much systemic disease can affect the oral hygiene and there is a strong relationship between periodontal disease and diabetes in which Periodontitis has been referred to as the sixth complication of diabetes ${ }^{(11)}$

The people with diabetes had significantly more clinical attachment loss than controls. In another cross-sectional study, Bridges and others found that diabetes affected all periodontal parameters ${ }^{(12)}$.

Oral health is an important component of overall health, well-being, and quality of life for institutionalized elders. Despite reports by dentists of the importance of oral hygiene, empirical evidence shows that daily oral care interventions have not been effective in safeguarding the oral and general health of this vulnerable population. Effective practice must involve not only recognizing its importance but also ensuring that daily oral hygiene receives the same priority as other care practices. ${ }^{(13)}$

So Taking care of your teeth can prevent expensive dental procedures in the future. And while regular dental visits do play an important role in overall care, small at-home remedies can help you get that million-dollar smile. Dr ShantanuJaradi offers a few tips... - Drink plenty of water. It is a natural mouthwash that can help reduce stains left by coffee, soda and ensure that you include a lot of fruits and vegetables in your diet. ${ }^{(14)}$

\section{General objectives:}

The objective of this study was to investigate and describe the effect of oral hygiene in prognosis of dental prosthesis of patients prosthodontics clinic 2012-2013.

\section{Specific objectives:}

- To distribute of patient according to gender, oral hygiene and periodontal disease.

- To distribute of patients according to losing of posterior teeth residency and systemic disease.
- To distribute of patients according to losing of posterior teeth and bad habits.

- To distribute of periodontal pocket (disease) among the patient.

- To distribute of patient according to gender, residency and the number of tooth brushing.

- To distribute of patient according to the frequency of gender and tooth brushing.

\section{MATERIALS AND METHODS}

- This research was done in faculty of dentistry of Aden university in prosthodontics department from 2013-2014. 240 cases (Hadhramoot, Aden, Laheeg and Taiz)- 60 cases for each province -were analyzed and divided into six groups: gender and oral hygiene, losing of posterior teeth residency and systemic disease, losing of posterior teeth and bad habits, periodontal pocket (disease) among the patient, number of tooth brushing and the frequency of gender tooth brushing in each provinces and frequency of gender and tooth brushing in general.

- Each patient complete a medical and dental history and signed an informed consent document. All patients accept oral examinations and each patient answer the case sheet applied in clinical examination.

- The chi-squared test was used to analyze the differences between the frequencies of in groups. group or subgroup were considered significantly different from each other if $<0.05$. All statically calculations were performed using the program SPSS 11.5 for windows.

\section{RESULTS}

Distribution of patient according gender, oral hygieneand periodontal disease in: 
TABLE (1) Hadhramoot

\begin{tabular}{|c|c|c|c|c|c|c|}
\hline & \multirow{2}{*}{\multicolumn{3}{|c|}{ Periodontal disease? }} & \multicolumn{2}{|c|}{ Oral hygiene } & \multirow{2}{*}{ Total } \\
\hline & & & & Good hygiene & Bad hygiene & \\
\hline \multirow[t]{6}{*}{ Yes } & Gender & \multirow{2}{*}{ Male } & Count & 6 & 9 & 15 \\
\hline & & & $\%$ of Total & $26.1 \%$ & $39.1 \%$ & $65.2 \%$ \\
\hline & & \multirow{2}{*}{ Female } & Count & 7 & 1 & 8 \\
\hline & & & $\%$ of Total & $30.4 \%$ & $4.3 \%$ & $34.8 \%$ \\
\hline & & \multirow{2}{*}{ Total } & Count & 13 & 10 & 23 \\
\hline & & & $\%$ of Total & $56.5 \%$ & $43.5 \%$ & $100.0 \%$ \\
\hline \multirow[t]{6}{*}{ Yes } & Gender & \multirow{2}{*}{ Male } & Count & 8 & 13 & 21 \\
\hline & & & $\%$ of Total & $21.6 \%$ & $35.1 \%$ & $56.8 \%$ \\
\hline & & \multirow{2}{*}{ Female } & Count & 15 & 1 & 16 \\
\hline & & & $\%$ of Total & $40.5 \%$ & $2.7 \%$ & $43.2 \%$ \\
\hline & & \multirow{2}{*}{ Total } & Count & 23 & 14 & 37 \\
\hline & & & $\%$ of Total & $62.2 \%$ & $37.8 \%$ & $100.0 \%$ \\
\hline
\end{tabular}

In table (1): Patients with periodontal disease: In males: $26.1 \%$ with good oral hygiene and $39.1 \%$ with bad oral hygiene. In Females: $30.4 \%$ with good oral hygiene and $4.3 \%$ with bad oral hygiene.

TABLE (2) Taiz

\begin{tabular}{|c|c|c|c|c|c|c|}
\hline \multirow{2}{*}{\multicolumn{4}{|c|}{ Periodontal disease? }} & \multicolumn{2}{|c|}{ Oral hygiene } & \multirow{3}{*}{$\begin{array}{c}\text { Total } \\
17\end{array}$} \\
\hline & & & & Good hygiene & Bad hygiene & \\
\hline Yes & Gender & \multirow{2}{*}{ Male } & Count & 3 & 14 & \\
\hline & & & $\%$ of Total & $8.8 \%$ & $41.2 \%$ & $50.0 \%$ \\
\hline & & \multirow{2}{*}{ Female } & Count & 3 & 14 & 17 \\
\hline & & & $\%$ of Total & $8.8 \%$ & $41.2 \%$ & $50.0 \%$ \\
\hline & \multicolumn{2}{|c|}{ Total } & Count & 6 & 28 & 34 \\
\hline & & & $\%$ of Total & $17.6 \%$ & $82.4 \%$ & $100.0 \%$ \\
\hline \multirow[t]{6}{*}{ Yes } & Gender & \multirow{2}{*}{ Male } & Count & 6 & 4 & 10 \\
\hline & & & $\%$ of Total & $23.1 \%$ & $15.4 \%$ & $38.5 \%$ \\
\hline & & \multirow{2}{*}{ Female } & Count & 10 & 6 & 16 \\
\hline & & & $\%$ of Total & $38.5 \%$ & $23.1 \%$ & $61.5 \%$ \\
\hline & & \multirow{2}{*}{ Total } & Count & 16 & 10 & 26 \\
\hline & & & $\%$ of Total & $61.5 \%$ & $38.5 \%$ & $100.0 \%$ \\
\hline
\end{tabular}

In table (2): Patients with periodontal disease: In males:8.8\% with good oral hygiene and $41.2 \%$ with bad oral hygiene. In females:8.8\% with good oral hygiene and $41.2 \%$ with bad oral hygiene. 
TABLE (3) Laheeg

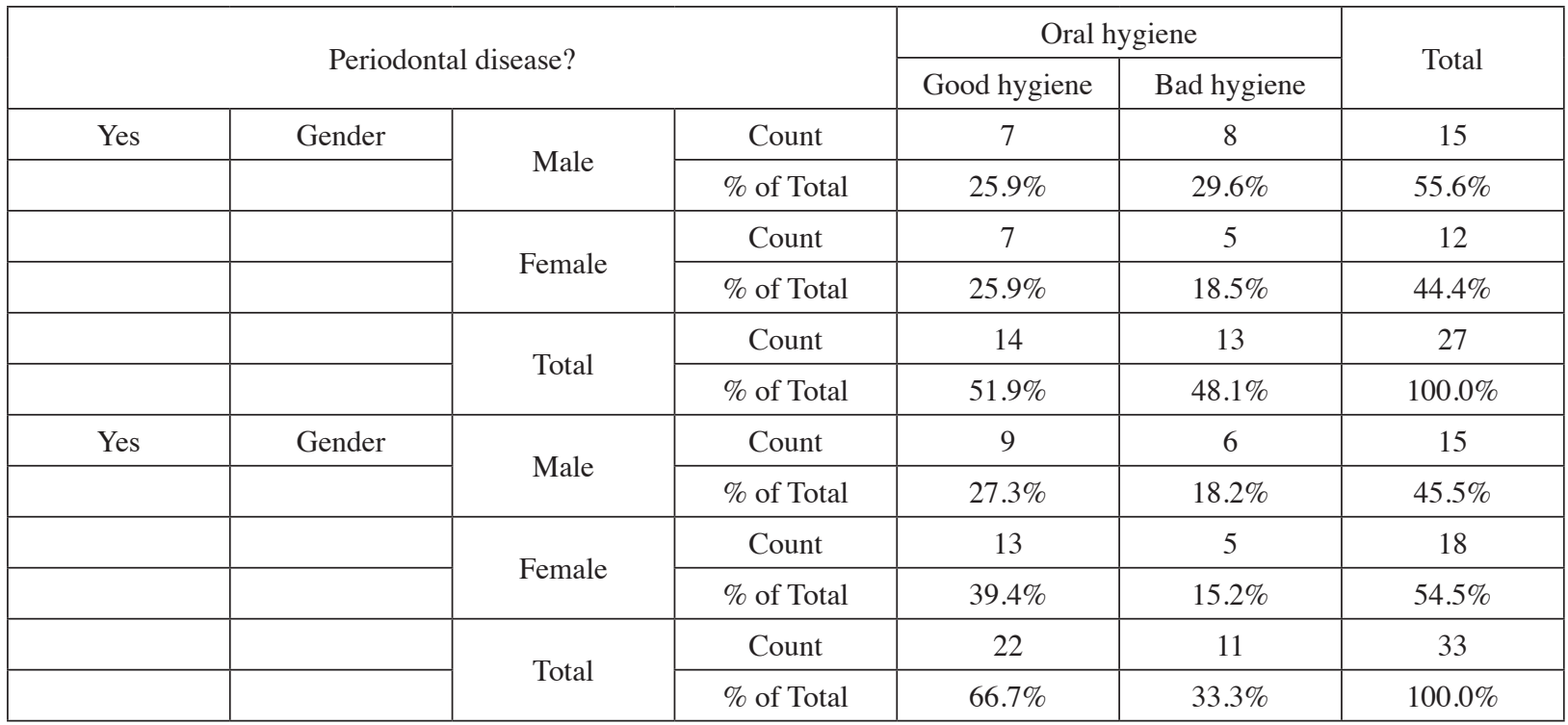

In table(3): Patients with periodontal disease: In males: $25.9 \%$ with good oral hygiene and $29.6 \%$ with bad oral hygiene. In females: $25.9 \%$ with good oral hygiene and $18.5 \%$ with bad oral hygiene.

TABLE (4) Aden

\begin{tabular}{|c|c|c|c|c|c|c|}
\hline \multirow{2}{*}{\multicolumn{4}{|c|}{ Periodontal disease? }} & \multicolumn{2}{|c|}{ Oral hygiene } & \multirow{3}{*}{$\begin{array}{c}\text { Total } \\
18\end{array}$} \\
\hline & & & & Good hygiene & Bad hygiene & \\
\hline Yes & Gender & \multirow{2}{*}{ Male } & Count & 4 & 14 & \\
\hline & & & $\%$ of Total & $13.8 \%$ & $48.3 \%$ & $62.1 \%$ \\
\hline & & \multirow{2}{*}{ Female } & Count & 5 & 6 & 11 \\
\hline & & & $\%$ of Total & $17.2 \%$ & $20.7 \%$ & $37.9 \%$ \\
\hline & & \multirow{2}{*}{ Total } & Count & 9 & 20 & 29 \\
\hline & & & $\%$ of Total & $31.0 \%$ & $69.0 \%$ & $100.0 \%$ \\
\hline \multirow[t]{6}{*}{ Yes } & Gender & \multirow{2}{*}{ Male } & Count & 11 & 10 & 21 \\
\hline & & & $\%$ of Total & $35.5 \%$ & $32.3 \%$ & $67.7 \%$ \\
\hline & & \multirow{2}{*}{ Female } & Count & 6 & 4 & 10 \\
\hline & & & $\%$ of Total & $19.4 \%$ & $12.9 \%$ & $32.3 \%$ \\
\hline & & \multirow{2}{*}{ Total } & Count & 17 & 14 & 31 \\
\hline & & & $\%$ of Total & $54.8 \%$ & $45.2 \%$ & $100.0 \%$ \\
\hline
\end{tabular}

In table (4): Patients with periodontal disease: Im males: $13.8 \%$ with good oral hygiene and $48.3 \%$ with bad oral hygiene. In females: $17.2 \%$ with good oral hygiene and 20.7 with bad oral hygiene. 
TABLE (5) Comparison between the provinces according to the residency, oral hygiene and periodontal disease:

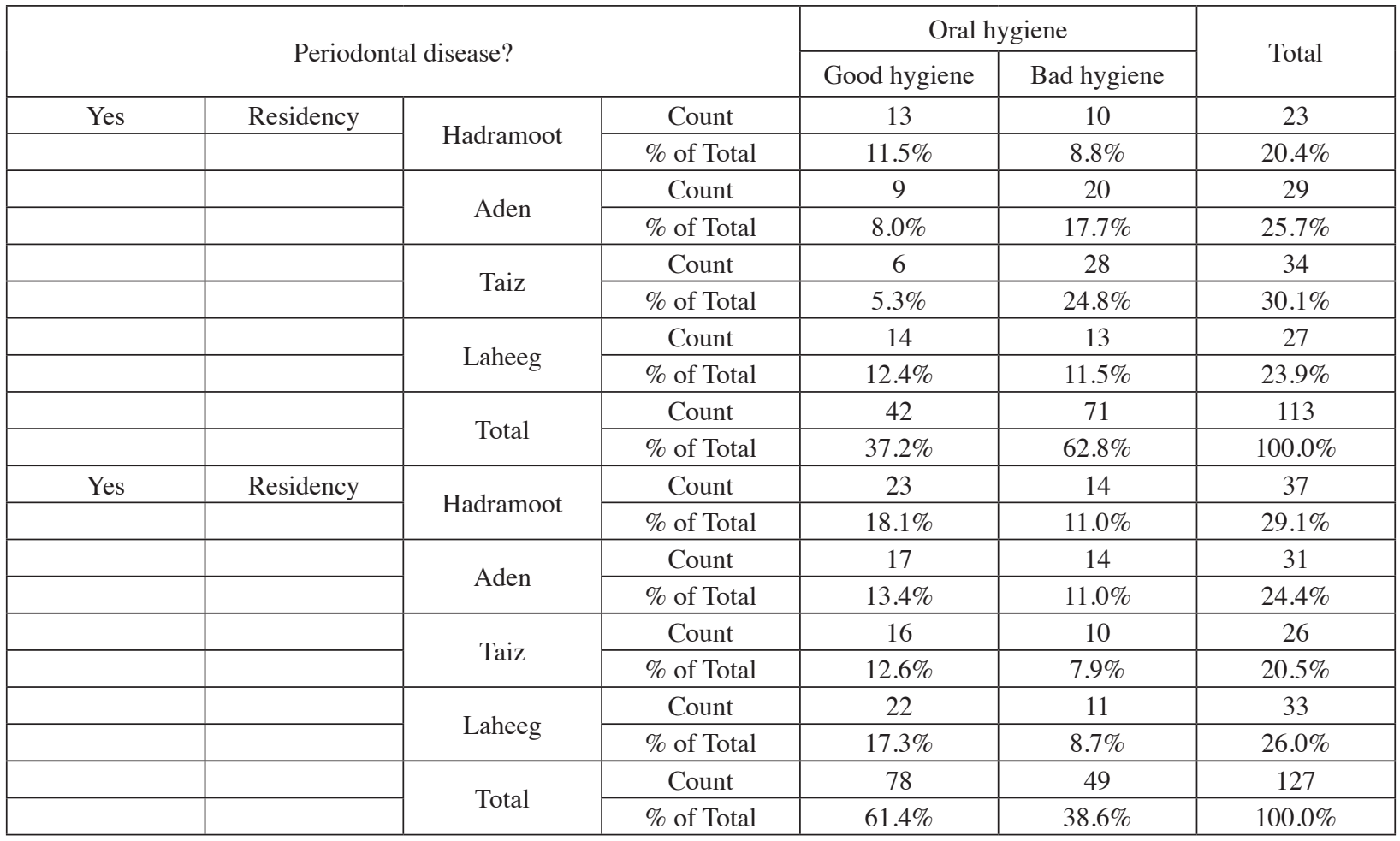

TABLE (6) Comparison between the provinces according to residency ,oral hygiene and gender

\begin{tabular}{|c|c|c|c|c|c|c|}
\hline \multirow{2}{*}{\multicolumn{4}{|c|}{ Gender }} & \multicolumn{2}{|c|}{ Oral hygiene } & \multirow{3}{*}{$\begin{array}{c}\text { Total } \\
36\end{array}$} \\
\hline & & & & \multirow{2}{*}{$\begin{array}{c}\text { Good hygiene } \\
14\end{array}$} & \multirow{2}{*}{$\frac{\text { Bad hygiene }}{22}$} & \\
\hline Male & Residency & \multirow{2}{*}{ Hadramoot } & Count & & & \\
\hline & & & $\%$ of Total & $10.6 \%$ & $16.7 \%$ & $27.3 \%$ \\
\hline & & \multirow{2}{*}{ Aden } & Count & 15 & 24 & 39 \\
\hline & & & $\%$ of Total & $11.4 \%$ & $18.2 \%$ & $29.5 \%$ \\
\hline & & \multirow{2}{*}{ Taiz } & Count & 9 & 18 & 27 \\
\hline & & & $\%$ of Total & $6.8 \%$ & $13.6 \%$ & $20.5 \%$ \\
\hline & & \multirow{2}{*}{ Laheeg } & Count & 16 & 14 & 30 \\
\hline & & & $\%$ of Total & $12.1 \%$ & $10.6 \%$ & $22.7 \%$ \\
\hline & & \multirow{2}{*}{ Total } & Count & 54 & 78 & 132 \\
\hline & & & $\%$ of Total & $40.9 \%$ & $59.1 \%$ & $100.0 \%$ \\
\hline \multirow[t]{10}{*}{ Female } & Residency & \multirow{2}{*}{ Hadramoot } & Count & 22 & 2 & 24 \\
\hline & & & $\%$ of Total & $20.4 \%$ & $1.9 \%$ & $22.2 \%$ \\
\hline & & \multirow{2}{*}{ Aden } & Count & 11 & 10 & 21 \\
\hline & & & $\%$ of Total & $10.2 \%$ & $9.3 \%$ & $19.4 \%$ \\
\hline & & \multirow{2}{*}{ Taiz } & Count & 13 & 20 & 33 \\
\hline & & & $\%$ of Total & $12.0 \%$ & $18.5 \%$ & $30.6 \%$ \\
\hline & & \multirow{2}{*}{ Laheeg } & Count & 20 & 10 & 30 \\
\hline & & & $\%$ of Total & $18.5 \%$ & $9.3 \%$ & $27.8 \%$ \\
\hline & & \multirow{2}{*}{ Total } & Count & 66 & 42 & 108 \\
\hline & & & $\%$ of Total & $61.1 \%$ & $38.9 \%$ & $100.0 \%$ \\
\hline
\end{tabular}


Distribution of patients according losing of posterior teeth residency and systemic disease:

TABLE (7) Hadhramoot:

\begin{tabular}{|c|c|c|c|c|c|}
\hline \multirow{2}{*}{\multicolumn{3}{|c|}{ Any associated systemic diseases? }} & \multicolumn{2}{|c|}{ losing posterior teeth? } & \multirow{3}{*}{$\begin{array}{c}\text { Total } \\
56\end{array}$} \\
\hline & & & yes & no & \\
\hline & \multirow{2}{*}{ normal } & Count & 28 & 28 & \\
\hline & & $\%$ of Total & $46.7 \%$ & $46.7 \%$ & $93.3 \%$ \\
\hline & \multirow{2}{*}{ cardiovascular disease } & Count & 0 & 1 & 1 \\
\hline & & $\%$ of Total & $.0 \%$ & $1.7 \%$ & $1.7 \%$ \\
\hline & \multirow{2}{*}{ respiratory disease } & Count & 0 & 1 & 1 \\
\hline & & $\%$ of Total & $.0 \%$ & $1.7 \%$ & $1.7 \%$ \\
\hline & \multirow{2}{*}{$\begin{array}{l}\text { endocrine (diabetes) and } \\
\text { cardiovascular disease }\end{array}$} & Count & 1 & 0 & 1 \\
\hline & & $\%$ of Total & $1.7 \%$ & $.0 \%$ & $1.7 \%$ \\
\hline & \multirow{2}{*}{ ENT disease } & Count & 1 & 0 & 1 \\
\hline & & $\%$ of Total & $1.7 \%$ & $.0 \%$ & $1.7 \%$ \\
\hline & \multirow{2}{*}{ Total } & Count & 30 & 30 & 60 \\
\hline & & $\%$ of Total & $50.0 \%$ & $50.0 \%$ & $100.0 \%$ \\
\hline
\end{tabular}

From 60 case only 1 case lost posterior teeth with diabetes and 1 case with ENT.

$46.7 \%$ of patients lost their teeth without association of systemic diseases and $3.3 \%$ with systemic diseases.

TABLE (8) Taiz

\begin{tabular}{|c|c|c|c|c|c|}
\hline \multirow{2}{*}{\multicolumn{3}{|c|}{ Any associated systemic diseases? }} & \multicolumn{2}{|c|}{ losing posterior teeth? } & \multirow[t]{2}{*}{ Total } \\
\hline & & & yes & no & \\
\hline & normal & $\%$ of Total & $10.0 \%$ & $41.7 \%$ & $51.7 \%$ \\
\hline & \multirow{2}{*}{ endocrine (diabetes) disease } & & & & \\
\hline & & $\%$ of Total & $20.0 \%$ & $.0 \%$ & $20.0 \%$ \\
\hline & \multirow{2}{*}{ cardiovascular disease } & & & & \\
\hline & & $\%$ of Total & $8.3 \%$ & $6.7 \%$ & $15.0 \%$ \\
\hline & \multirow[t]{2}{*}{ renal disease } & & & & \\
\hline & & $\%$ of Total & $.0 \%$ & $1.7 \%$ & $1.7 \%$ \\
\hline & \multirow{2}{*}{$\begin{array}{l}\text { endocrine (diabetes) and } \\
\text { cardiovascular disease }\end{array}$} & & & & \\
\hline & & $\%$ of Total & $5.0 \%$ & $1.7 \%$ & $6.7 \%$ \\
\hline & \multirow{2}{*}{ renal and cardiovascular disease } & Count & 1 & 0 & 1 \\
\hline & & $\%$ of Total & $1.7 \%$ & $.0 \%$ & $1.7 \%$ \\
\hline & \multirow{2}{*}{ renal and endocrine(diabetes) disease } & Count & 2 & 0 & 2 \\
\hline & & $\%$ of Total & $3.3 \%$ & $.0 \%$ & $3.3 \%$ \\
\hline & \multirow{2}{*}{ Total } & Count & 29 & 31 & 60 \\
\hline & & $\%$ of Total & $48.3 \%$ & $51.7 \%$ & $100.0 \%$ \\
\hline
\end{tabular}

$10 \%$ of patients lost their teeth without association of systemic diseases and $38.3 \%$ with systemic diseases. 
TABLE (9) Laheeg

\begin{tabular}{|c|c|c|c|c|c|}
\hline \multirow{2}{*}{\multicolumn{3}{|c|}{ Any associated systemic diseases? }} & \multicolumn{2}{|c|}{ losing posterior teeth? } & \multirow[t]{2}{*}{ Total } \\
\hline & & & yes & no & \\
\hline & \multirow{2}{*}{ normal } & Count & 32 & 10 & 42 \\
\hline & & $\%$ of Total & $53.3 \%$ & $16.7 \%$ & $70.0 \%$ \\
\hline & \multirow{2}{*}{ endocrine (diabetes) disease } & Count & 7 & 1 & 8 \\
\hline & & $\%$ of Total & $11.7 \%$ & $1.7 \%$ & $13.3 \%$ \\
\hline & \multirow{2}{*}{ cardiovascular disease } & Count & 7 & 2 & 9 \\
\hline & & $\%$ of Total & $11.7 \%$ & $3.3 \%$ & $15.0 \%$ \\
\hline & \multirow{2}{*}{$\begin{array}{l}\text { endocrine (diabetes) and } \\
\text { cardiovascular disease }\end{array}$} & Count & 1 & 0 & 1 \\
\hline & & $\%$ of Total & $1.7 \%$ & $.0 \%$ & $1.7 \%$ \\
\hline & \multirow{2}{*}{ Total } & Count & 47 & 13 & 60 \\
\hline & & $\%$ of Total & $78.3 \%$ & $21.7 \%$ & $100.0 \%$ \\
\hline
\end{tabular}

In Table (9): $53.3 \%$ of patients lost their teeth without association of systemic diseases and $26 \%$ with systemic diseases.

TABLE (10) Aden

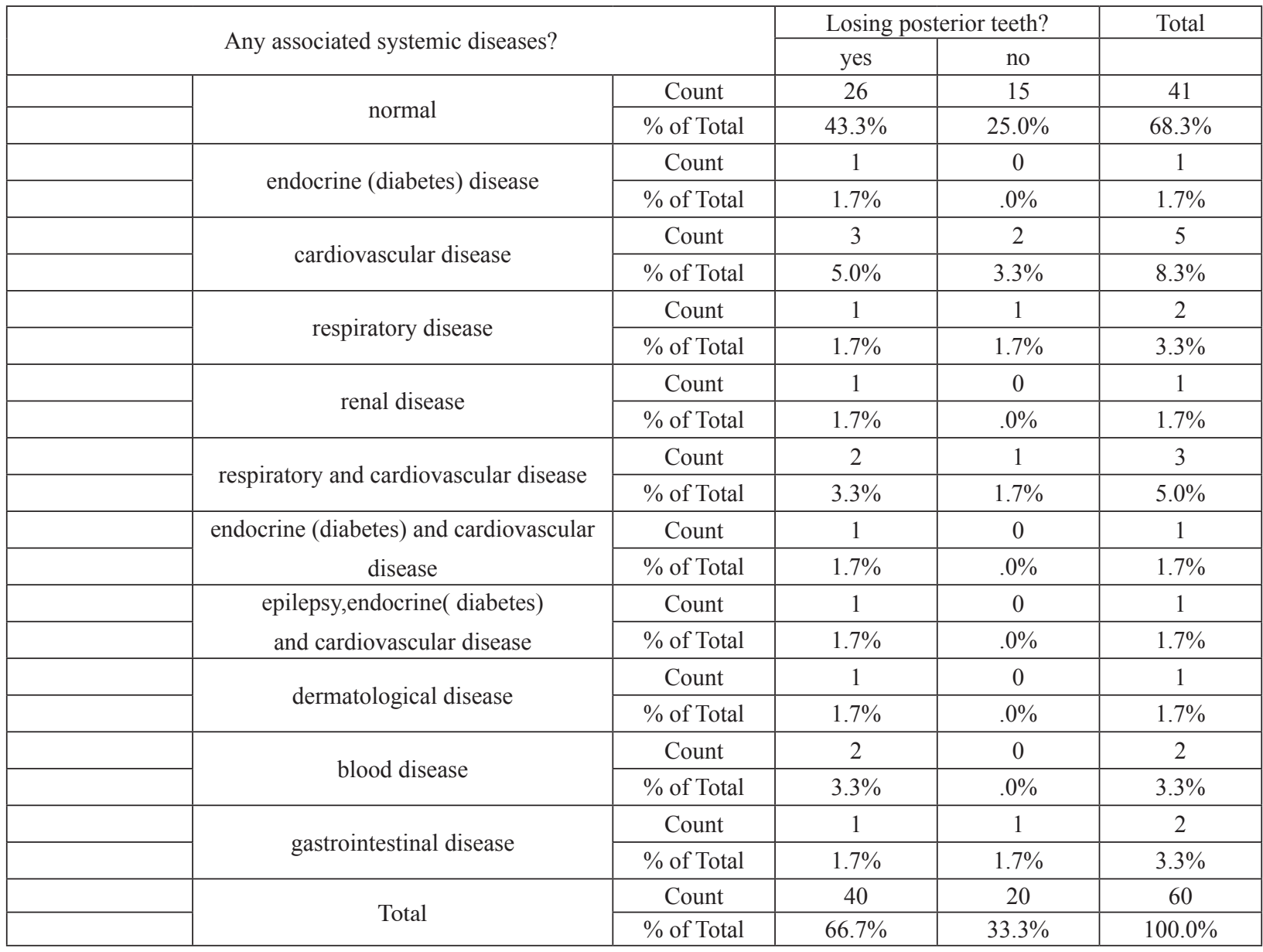

In Table (10) $43.3 \%$ of patients lost their teeth without association of systemic diseases and $23.4 \%$ with systemic diseases. 
TABLE (11) Comparison between all provinces and residency in one table

\begin{tabular}{|c|c|c|c|c|c|c|c|}
\hline & \multirow{2}{*}{\multicolumn{2}{|c|}{ Losing posterior teeth? }} & \multicolumn{4}{|c|}{ residency } & \multirow{3}{*}{$\begin{array}{l}\text { Total } \\
63.0 \%\end{array}$} \\
\hline & & & \multirow{2}{*}{$\begin{array}{c}\text { Hadramoot } \\
19.2 \%\end{array}$} & \multirow{2}{*}{$\begin{array}{c}\text { Aden } \\
17.8 \%\end{array}$} & \multirow{2}{*}{$\begin{array}{c}\text { Taiz } \\
4.1 \%\end{array}$} & \multirow{2}{*}{$\begin{array}{l}\text { Laheeg } \\
21.9 \%\end{array}$} & \\
\hline yes & $\begin{array}{c}\text { Any associated } \\
\text { systemic diseases? }\end{array}$ & normal & & & & & \\
\hline & & endocrine (diabetes) disease & & $.7 \%$ & $8.2 \%$ & $4.8 \%$ & $13.7 \%$ \\
\hline & & cardiovascular disease & & $2.1 \%$ & $3.4 \%$ & $4.8 \%$ & $10.3 \%$ \\
\hline & & respiratory disease & & $.7 \%$ & & & $.7 \%$ \\
\hline & & renal disease & & $.7 \%$ & & & $.7 \%$ \\
\hline & & $\begin{array}{l}\text { respiratory and cardiovascular } \\
\text { disease }\end{array}$ & & $1.4 \%$ & & & $1.4 \%$ \\
\hline & & $\begin{array}{l}\text { endocrine (diabetes) and } \\
\text { cardiovascular disease }\end{array}$ & $.7 \%$ & $.7 \%$ & $2.1 \%$ & $.7 \%$ & $4.1 \%$ \\
\hline & & $\begin{array}{l}\text { epilepsy,endocrine( diabetes) and } \\
\text { cardiovascular disease }\end{array}$ & & $.7 \%$ & & & $.7 \%$ \\
\hline & & dermatological disease & & $.7 \%$ & & & $.7 \%$ \\
\hline & & ENT disease & $.7 \%$ & & & & $.7 \%$ \\
\hline & & renal and cardiovascular disease & & & $.7 \%$ & & $.7 \%$ \\
\hline & & $\begin{array}{l}\text { renal and endocrine(diabetes) } \\
\text { disease }\end{array}$ & & & $1.4 \%$ & & $1.4 \%$ \\
\hline & & blood disease & & $1.4 \%$ & & & $1.4 \%$ \\
\hline & & gastrointestinal disease & & $.7 \%$ & & & $.7 \%$ \\
\hline & & Total & $20.5 \%$ & $27.4 \%$ & $19.9 \%$ & $32.2 \%$ & $100.0 \%$ \\
\hline \multirow[t]{9}{*}{ no } & $\begin{array}{c}\text { Any associated } \\
\text { systemic diseases? }\end{array}$ & normal & $29.8 \%$ & $16.0 \%$ & $26.6 \%$ & $10.6 \%$ & $83.0 \%$ \\
\hline & & endocrine (diabetes) disease & & & & $1.1 \%$ & $1.1 \%$ \\
\hline & & cardiovascular disease & $1.1 \%$ & $2.1 \%$ & $4.3 \%$ & $2.1 \%$ & $9.6 \%$ \\
\hline & & respiratory disease & $1.1 \%$ & $1.1 \%$ & & & $2.1 \%$ \\
\hline & & renal disease & & & $1.1 \%$ & & $1.1 \%$ \\
\hline & & $\begin{array}{l}\text { respiratory and cardiovascular } \\
\text { disease }\end{array}$ & & $1.1 \%$ & & & $1.1 \%$ \\
\hline & & $\begin{array}{l}\text { endocrine (diabetes ) and } \\
\text { cardiovascular disease }\end{array}$ & & & $1.1 \%$ & & $1.1 \%$ \\
\hline & & gastrointestinal disease & & $1.1 \%$ & & & $1.1 \%$ \\
\hline & & Total & $31.9 \%$ & $21.3 \%$ & $33.0 \%$ & $13.8 \%$ & $100.0 \%$ \\
\hline
\end{tabular}

In Table (11); the total percentage of endocrine (diabetes) disease alone (13.7\%) and with associated with other diseases is $19.9 \%$. Percentage of Cardiovascular disease alone (10.3\%) and with association with other diseases is $16.5 \%$. 
Distribution of patients according losing of posterior teeth and bad habits:

TABLE (12) Hadramoot

\begin{tabular}{|c|c|c|c|c|c|}
\hline & & & losing & teeth? & Total \\
\hline & & & yes & no & 10tal \\
\hline any bad habits? & No & Count & 21 & 20 & 41 \\
\hline & NO & $\%$ of Total & $35.0 \%$ & $33.3 \%$ & $68.3 \%$ \\
\hline & gat chewing & Count & 3 & 3 & 6 \\
\hline & qat cnewing & $\%$ of Total & $5.0 \%$ & $5.0 \%$ & $10.0 \%$ \\
\hline & Smoking & Count & 0 & 2 & 2 \\
\hline & NHIUNm! & $\%$ of Total & $.0 \%$ & $3.3 \%$ & $3.3 \%$ \\
\hline & tobacco chewing & Count & 3 & 1 & 4 \\
\hline & 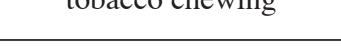 & $\%$ of Total & $5.0 \%$ & $1.7 \%$ & $6.7 \%$ \\
\hline & smokino and $g$ at chewino & Count & 3 & 3 & 6 \\
\hline & 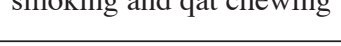 & $\%$ of Total & $5.0 \%$ & $5.0 \%$ & $10.0 \%$ \\
\hline & gat and tobacco chewing & Count & 0 & 1 & 1 \\
\hline & 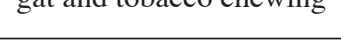 & $\%$ of Total & $.0 \%$ & $1.7 \%$ & $1.7 \%$ \\
\hline & tal & Count & 30 & 30 & 60 \\
\hline & Jal & $\%$ of Total & $50.0 \%$ & $50.0 \%$ & $100.0 \%$ \\
\hline
\end{tabular}

In Table (12):15 \% of posterior teeth are lost due to bad habits Qat chewing is the most common cause of tooth loss.

TABLE (13) Taiz

\begin{tabular}{|c|c|c|c|c|c|}
\hline & \multicolumn{2}{|c|}{ losing posterior teeth? } & \multirow{2}{*}{ Total } \\
\hline & & & yes & no & \\
\hline Any bad habits? & \multirow{2}{*}{ No } & Count & 8 & 16 & 24 \\
\hline & & $\%$ of Total & $13.3 \%$ & $26.7 \%$ & $40.0 \%$ \\
\hline & \multirow{2}{*}{ qat chewing } & Count & 12 & 8 & 20 \\
\hline & & $\%$ of Total & $20.0 \%$ & $13.3 \%$ & $33.3 \%$ \\
\hline & \multirow{2}{*}{ smoking } & Count & 3 & 1 & 4 \\
\hline & & $\%$ of Total & $5.0 \%$ & $1.7 \%$ & $6.7 \%$ \\
\hline & \multirow{2}{*}{ smoking and qat chewing } & Count & 2 & 2 & 4 \\
\hline & & $\%$ of Total & $3.3 \%$ & $3.3 \%$ & $6.7 \%$ \\
\hline & \multirow{2}{*}{ Shmma } & Count & 1 & 0 & 1 \\
\hline & & $\%$ of Total & $1.7 \%$ & $.0 \%$ & $1.7 \%$ \\
\hline & \multirow{2}{*}{ Shisha } & Count & 3 & 1 & 4 \\
\hline & & $\%$ of Total & $5.0 \%$ & $1.7 \%$ & $6.7 \%$ \\
\hline & \multirow{2}{*}{ shesha and qat chewing } & Count & 0 & 1 & 1 \\
\hline & & $\%$ of Total & $.0 \%$ & $1.7 \%$ & $1.7 \%$ \\
\hline & \multirow{2}{*}{ nail bitting } & Count & 0 & 2 & 2 \\
\hline & & $\%$ of Total & $.0 \%$ & $3.3 \%$ & $3.3 \%$ \\
\hline & \multirow{2}{*}{ Total } & Count & 29 & 31 & 60 \\
\hline & & $\%$ of Total & $48.3 \%$ & $51.7 \%$ & $100.0 \%$ \\
\hline
\end{tabular}

In Table (13): $37 \%$ of posterior teeth are lost due to bad habits.Qat chewing is the most common cause of tooth loss. 
TABLE (14) Laheeg:

\begin{tabular}{|c|c|c|c|c|c|}
\hline & & & losing $\mathrm{pc}$ & or teeth? & Total \\
\hline & & & yes & no & \\
\hline Any bad habits? & $n p_{0}$ & Count & 22 & 8 & 30 \\
\hline & 110 & $\%$ of Total & $36.7 \%$ & $13.3 \%$ & $50.0 \%$ \\
\hline & ant ohourinc & Count & 14 & 2 & 16 \\
\hline & qat chewing & $\%$ of Total & $23.3 \%$ & $3.3 \%$ & $26.7 \%$ \\
\hline & tohososobrino & Count & 3 & 0 & 3 \\
\hline & tooacco cnewing & $\%$ of Total & $5.0 \%$ & $.0 \%$ & $5.0 \%$ \\
\hline & omoling and ant abourin & Count & 6 & 2 & 8 \\
\hline & smoking and qat chewing & $\%$ of Total & $10.0 \%$ & $3.3 \%$ & $13.3 \%$ \\
\hline & 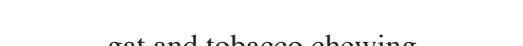 & Count & 0 & 1 & 1 \\
\hline & sal and looacco cnewing & $\%$ of Total & $.0 \%$ & $1.7 \%$ & $1.7 \%$ \\
\hline & hruxism & Count & 1 & 0 & 1 \\
\hline & Druxism & $\%$ of Total & $1.7 \%$ & $.0 \%$ & $1.7 \%$ \\
\hline & 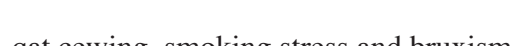 & Count & 1 & 0 & 1 \\
\hline & 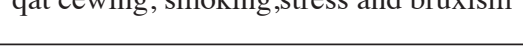 & $\%$ of Total & $1.7 \%$ & $.0 \%$ & $1.7 \%$ \\
\hline & Total & Count & 47 & 13 & 60 \\
\hline & Iotal & $\%$ of Total & $78.3 \%$ & $21.7 \%$ & $100.0 \%$ \\
\hline
\end{tabular}

In Table (14): $41.6 \%$ of posterior teeth are lost by bad habits.Qat chewing is the most common cause of tooth loss.

TABLE (15) Aden

\begin{tabular}{|c|c|c|c|c|c|}
\hline & & & \multicolumn{2}{|c|}{ losing posterior teeth? } & \multirow{2}{*}{ Total } \\
\hline & & & yes & no & \\
\hline \multirow[t]{14}{*}{ any bad habits? } & \multirow{2}{*}{ No } & Count & 25 & 14 & 39 \\
\hline & & $\%$ of Total & $41.7 \%$ & $23.3 \%$ & $65.0 \%$ \\
\hline & \multirow{2}{*}{ qat chewing } & Count & 6 & 3 & 9 \\
\hline & & $\%$ of Total & $10.0 \%$ & $5.0 \%$ & $15.0 \%$ \\
\hline & \multirow{2}{*}{ Smoking } & Count & 1 & 0 & 1 \\
\hline & & $\%$ of Total & $1.7 \%$ & $.0 \%$ & $1.7 \%$ \\
\hline & \multirow{2}{*}{ smoking and qat chewing } & Count & 7 & 1 & 8 \\
\hline & & $\%$ of Total & $11.7 \%$ & $1.7 \%$ & $13.3 \%$ \\
\hline & \multirow{2}{*}{ nail bitting } & Count & 1 & 0 & 1 \\
\hline & & $\%$ of Total & $1.7 \%$ & $.0 \%$ & $1.7 \%$ \\
\hline & \multirow{2}{*}{ smoking and shmma } & Count & 0 & 1 & 1 \\
\hline & & $\%$ of Total & $.0 \%$ & $1.7 \%$ & $1.7 \%$ \\
\hline & \multirow{2}{*}{ snuff dipping } & Count & 0 & 1 & 1 \\
\hline & & $\%$ of Total & $.0 \%$ & $1.7 \%$ & $1.7 \%$ \\
\hline \multirow{2}{*}{\multicolumn{2}{|c|}{ Total }} & Count & 40 & 20 & 60 \\
\hline & & $\%$ of Total & $66.7 \%$ & $33.3 \%$ & $100.0 \%$ \\
\hline
\end{tabular}

In Table (15): $26 \%$ of posterior teeth are lost by bad habits.Qat chewing is the most common cause of tooth loss. 
TABLE (16) Distribution of periodontal pocket (disease) among residency of patient

\begin{tabular}{|c|c|c|c|c|c|c|c|}
\hline & & & \multicolumn{4}{|c|}{ residency } & \multirow{2}{*}{ Total } \\
\hline & & & Hadramoot & Aden & Taiz & Laheeg & \\
\hline \multirow[t]{4}{*}{ periodontal pocket? } & Yes & Count & 23 & 29 & 34 & 27 & 113 \\
\hline & & $\%$ of Total & $9.6 \%$ & $12.1 \%$ & $14.2 \%$ & $11.3 \%$ & $47.1 \%$ \\
\hline & No & Count & 37 & 31 & 26 & 33 & 127 \\
\hline & & $\%$ of Total & $15.4 \%$ & $12.9 \%$ & $10.8 \%$ & $13.8 \%$ & $52.9 \%$ \\
\hline \multirow{2}{*}{\multicolumn{2}{|c|}{ Total }} & Count & 60 & 60 & 60 & 60 & 240 \\
\hline & & $\%$ of Total & $25.0 \%$ & $25.0 \%$ & $25.0 \%$ & $25.0 \%$ & $100.0 \%$ \\
\hline
\end{tabular}

In table (16) - $47.1 \%$ of cases have periodontal disease. $14.2 \%$ in Taiz.12.1\% in Aden while $11.3 \%$ in Laheeg and $9.6 \%$ in Hadramoot.

TABLE (17) Distribution of patient according to gender, residency and the number of tooth brushing:

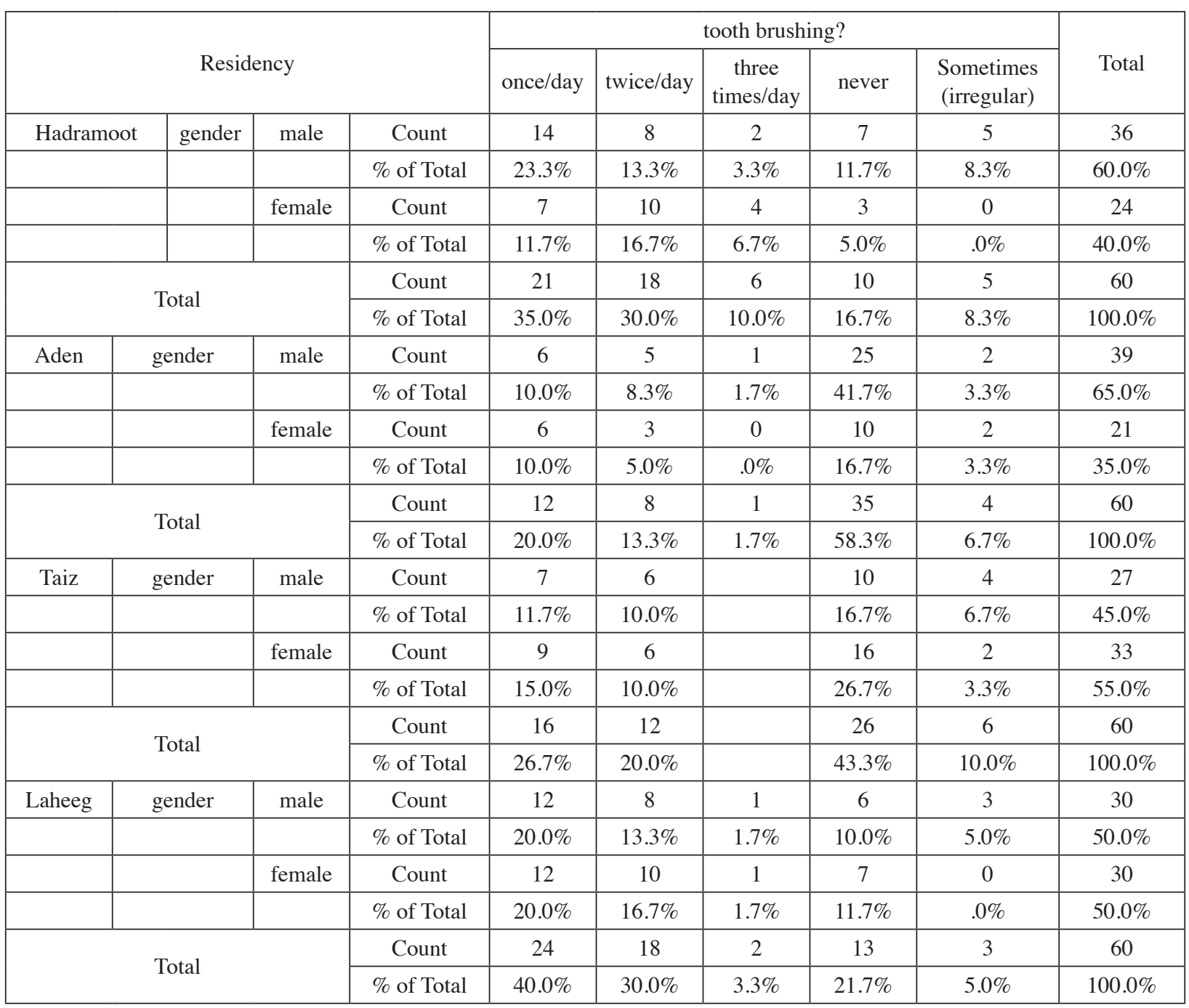


In table (17)

Hadramoot: The highest percentage of patients brushing their teeth once/day with $35 \%$ (males $23.3 \%$ and females $11.7 \%$ ).

Aden: The highest percentage of patients never brushing their teeth with $58.3 \%$ (males $41.7 \%$ and females $16.7 \%$ ).
Taiz: The highest percentage of patients never brushing their teeth with $43.3 \%$ (males $16.7 \%$ and females $26.7 \%$ ).

Laheeg: The highest percentage of patients brushing their teeth once/day with $40 \%$ (males $20 \%$ and females 20\%).

TABLE (18) Distribution of patient according to the frequency of gender tooth brushing

\begin{tabular}{|c|c|c|c|c|c|c|c|c|}
\hline & \multicolumn{5}{|c|}{ tooth brushing? } & \multirow[b]{2}{*}{ Total } \\
\hline & & & once/day & twice/day & $\begin{array}{c}\text { three } \\
\text { times/day }\end{array}$ & never & $\begin{array}{l}\text { sometimes } \\
\text { (irregular) }\end{array}$ & \\
\hline \multirow[t]{4}{*}{ Gender } & male & Count & 39 & 27 & 4 & 48 & 14 & 132 \\
\hline & & $\%$ of Total & $16.3 \%$ & $11.3 \%$ & $1.7 \%$ & $20.0 \%$ & $5.8 \%$ & $55.0 \%$ \\
\hline & female & Count & 34 & 29 & 5 & 36 & 4 & 108 \\
\hline & & $\%$ of Total & $14.2 \%$ & $12.1 \%$ & $2.1 \%$ & $15.0 \%$ & $1.7 \%$ & $45.0 \%$ \\
\hline \multicolumn{2}{|c|}{ Total } & Count & 73 & 56 & 9 & 84 & 18 & 240 \\
\hline & & $\%$ of Total & $30.4 \%$ & $23.3 \%$ & $3.8 \%$ & $35.0 \%$ & $7.5 \%$ & $100.0 \%$ \\
\hline
\end{tabular}

In table (18):

$35 \%$ never brushing their teeth (males $20 \%$ and females $15 \%$ ).

$30 \%$ brushing their teeth once/day (males $16.3 \%$ and females $14.2 \%$ ).

$23.3 \%$ brushing their teeth twice/day (males $11.3 \%$ and females $12.1 \%$ ).

\section{DISCUSSION}

There is a great relationship between the maintaining good oral hygiene and having a good and strong periodontal structure while the opposite is true, most people with bad habits as Qat chewing or those who never brushing their teeth (etc.) all these will lead to destruction of periodontum and eventually loss of teeth.

According to the World Health Organization (WHO) criteria, by the age of 34 , teeth are usually extracted for caries, and later it is extracted because of periodontal disease ${ }^{(15)}$ Periodontal disease is a major cause of teeth loss and its incidence rises among old age people. This disease affects the supporting structure of the teeth, which includes primarily the alveolar bone. As the alveolar bone resorbs, the teeth becomes mobile and without proper intervention, and will eventually be lost. ${ }^{(16,17)}$

In our serach most of cases with bad oral hygiene in association with periodontal disease occur in males than in females. 
The highest percentage for males occurs in Aden with (48.3\%) and the highest percentage for females occurs in Taiz with (41.2\%) while the lowest percentage for males occurs in Laheeg with (29.6\%) while in females the lowest percentage occurs in Hadhramoot with (4.3\%).

There is an association between the systemic diseases and there effect in the general and oral health, this effect may reflect in the defense mechanism of the body and the oral system.

The most common disease affect the oral system is diabetes but it is concluded that inadequate metabolic control, dental calculus and longstanding diabetes can increase the risk of periodontitis as well as teeth loss. On the other hand, diabetics, who regularly control their disease and oral health through self-care and regular dental and oral professional care, have a lower risk of teeth loss. ${ }^{(15)}$

in our research the highest percentage of systemic diseases associated with the loss of teeth is diabetes disease with a percentage $19.9 \%$ of all systemic diseases then cardiovascular diseases with a percentage of $16.5 \%$. This results is agree with results of other researches made in the world for example, in a study made in Aden university/ republic of Yemen in the faculty of dentistry in the period between 2009-2010 in which diabetes has the greatest percentage in association of periodontal disease with $(28 \%)$ of all systemic disease. Another study in Canada suggested that by the year 2010, it is expected that 3 million Canadians will be afflicted with diabetes mellitus ${ }^{.(15)}$ It has been reported that for every person known to have diabetes, there is someone else in whom the disease remains undiagnosed ${ }^{(15)}$.

In all provinces, Qat chewing is the most common cause of posterior teeth lost with more prevalence in Laheeg (23\%), Taiz (19\%), Aden(12\%) then Hadramoot $(5 \%)$ see table $(10,11,12,13)$.

When periodontal disease is initiated in the mouth and not treated early, it may result in rapid destruction of periodontal and supporting bone which finally lead to loss of tooth ${ }^{(18)}$.in our research we found that Taiz province has the highest percentage of patient have periodontal disease with percentage $14.2 \%$ then Aden with percentage 12.1 $\%$ after that Laheeg with $11.3 \%$ and finally Hadhramoot with $9.6 \%$ table (14). This give us a strong correlation between the oral hygiene and periodontal disease in which Taiz and Aden both have high percentage of patient with poor oral hygiene 63.3 $\%$ and $56.7 \%$ respectively see table (2)and (4).

The awareness of maintaining good oral hygiene is different from person to person and from males to females. In table (17) we see that in Hadramoot and Laheeg most of patients brushing their teeth once/day with (35\% (males $23.3 \%$ and females $11.7 \%)$ ) and (40\% (males $20 \%$ and females 20\%)) respectively while in Aden and Taiz the highest percentage of patients never brushing their teeth with $(58.3 \%$ (males $41.7 \%$ and females $16.7 \%)$ ) and $(43.3 \%$ (males $16.7 \%$ and females $26.7 \%$ )) respectively.

The awareness of patient to tooth brushing, the highest percentage of patients never brushing their teeth with $35 \%$ and males are more than females with $20 \%$ for males and $15 \%$ for females. Females have more concern about their teeth cleaning and they have the greatest percentage of cleaning their teeth twice /day $(12.1 \%)$ while males has $(11.3 \%)$ see table(18).

\section{CONCLUSION}

1. Female's patients are more concern with oral hygiene by more frequent tooth brushing.

2. Diabetes is the most frequent systemic disease associated with loss of teeth.

3. Maintain good oral hygiene will increase to long period time of usage and the prognosis of dental prosthesis. 


\section{REFERENCES}

1. Hollister MC, Weintraub JA. The association of oral status with systemic health, quality of life, and economic productivity. Journal of Dental Education 1993; 57(12): 901-12.

2. Fisher EB, Fitzgibbon ML, Glasgow RE, Haire-Joshu D, Hayman LL, Kaplan RM, Nanney MS, Ockene JK. Behavior matters. American Journal of Preventive Medicine 2011; 40(5): e15-30.

3. Misch CE. Dental Implant Prosthetics, Mosby 2004.

4. Evren BA, Uludamar A, Işeri U, Ozkan YK. The association between socioeconomic status, oral hygiene practice, denture stomatitis and oral status in elderly people living different residential homes. Arch Gerontol Geriatr 2011; 53: 252-7.

5. Jeganathan S, Thean HP, Thong KT, Chan YC, Singh M. A clinically viable index for quantifying denture plaque. Quintessence Int. 1996; 27: 569-73.

6. Tan MH and MacLean DR. Epidemiology of diabetes mellitus in Canada. Clin Invest Med 1995; 18(4):240-6.

7. Paranhos HF, Silva-Lovato CH, Souza RF, Cruz PC, Freitas KM, Peracini A. Effects of mechanical and chemical methods on denture biofilm accumulation. J Oral Rehabil 2007; 8: 606-12.

8. Paranhos H de F, da Silva CH, Venezian GC, Macedo LD, de Souza RF. Distribution of biofilm on internal and external surfaces of upper complete dentures: the effect of hygiene instruction. Gerodontology 2007; 24: 162-8.

9. Souza RF, Regis RR, Nascimento C, Paranhos HF, Silva $\mathrm{CH}$. Domestic use of a disclosing solution for denture hygiene: a randomised trial. Gerodontology 2010; 27: 193-8.
10. Abelson DC. Denture plaque and denture cleansers: review of the literature. Gerodontics 1985; 1: 202-6.

11. Loe H. Periodontal disease The sixth complication of diabetes mellitus. Diabetes Care 1993; 16(1):329-34.

12. Bridges RB, Anderson JW, Saxe SR, Gregory K, Bridges SR. Periodontal status of diabetic and non diabetic men: effects of smoking, glycemiccontrol, and socioeconomic factors. J Periodontol. 1996 Nov;67(11):1185-92.

13. Cornejo-Ovalle M, Costa-de-Lima K, Pérez G, Borrell C, CasalsPeidro E. Oral health care activities performed by caregivers for Institutionali-zed elderly in Barcelona-Spain. Med Oral Patol Oral Cir Bucal. 2013 Jul 1;18 (4):e641-9.

14. Ivana Cukovic, Bagic, Zeliko Verzak, Nikica. Tooth loss among diabetic patients, University of Zagreb, Croatia Car, Antoinette Care J 2002; P23-26.

15. Grossi SG and Genco RJ. Periodontal disease and diabetes mellitus : a two - way relationship Ann periodontal 1998; P:51-63.

16. Tan M, Daneman D, Lau D et al. Diabetes in Canada2000.: strategies towards. In: Canadian Diabetes Advisory Board; 1997; Toronto; 1997.p

17. Takamiya AS, Monteiro DR, Barão VA, Pero AC, Compagnoni MA, Barbosa DB. Complete denture hygiene and nocturnal wearing habits among patients attending the Prosthodontic Department in a Dental University in Brazil. 8- http:// articles. timesofindia. indiatimes. com/ keyword/oral-hygiene.

18. Nora SILVA, Loreto ABUSLEME, Denisse BRAVO, Nicolás DUTZAN et al. Host response mechanisms in periodontal diseases. Journal of Applied Oral Science 2015;23:3, 329-355. 